\title{
INDOMARET MILIK SIAPA? \\ IMPLEMENTASI DAN PEMINGGIRAN PEDAGANG KECIL DALAM PRAKTEK PEMBERIAN IZIN MENDIRIKAN TOKO MODERN DI MEULABOH
}

\author{
Fatma Wati ${ }^{1}$, Mursyidin ${ }^{2}$, Vellayati Hajad ${ }^{3 *}$ \\ ${ }^{1}$ Jurusan Ilmu Administrasi Negara \\ Universitas Teuku Umar \\ Email: fatmawatisy06@gmail.com \\ 2 Jurusan Sosiologi \\ Universitas Malikussaleh/Universitas Teuku Umar \\ Email:mursyidinza@unimal.ac.id \\ 3 Jurusan IImu Administrasi Negara \\ Universitas Teuku Umar \\ Email: vellayati.hajad@utu.ac.id
}

\begin{abstract}
Abstrak
Implementasi Peraturan Menteri Perdagangan Republik tentang kehadiran toko modern seperti indomaret di Kota Meulaboh Kabupaten Aceh Barat yang berdampak pada banyaknya jumlah indomaret dan mengganggu eksistensi toko tradisonal milik masyarakat setempat. Penelitian ini menggunakan metode kualitatif melalui pendekatan studi kasus (case-study) dengan narasumber Kepala Bidang Perdagangan di Dinas Perdagangan, Kasi Pelayanan dan Staff Perizinan Dinas Penanaman Modal dan Pelayanan Terpadu Satu Pintu (DPMPTSP), Sekretaris Ikatan Pedagang Aceh Barat, Karyawan Toko Modern (Indomaret), Pedagang Tradisional/Pedagang Kelontong dan Masyarakat. Hasil penelitian ini menunjukkan bahwa pelaksanaan implementasi yang diterbitkan Permendagri terutama terkait pedoman penataan dan pembinaan pasar tradisional, pusat perbelanjaan dan toko modern yang dilaksanakan oleh Pemerintah Daerah Kabupaten Aceh Barat belum sepenuhnya berjalan dengan efektif, hal tersebut dikarenakan belum adanya kebijakan turunan yang mengatur lebih lanjut terkait pendirian pasar modern seperti indomaret, dan dalam implementasi tersebut juga terdapat misskomunikasi dan non-koordinasi diantara dua pihak pelaksana kebijakan. Selain memberikan dampak positif seperti dapat meningkatkkan pajak pendapatan asli daerah, namun kehadiran indomaret juga memberikan dampak negatif karena semakin meminggirkan dan bahkan mematikan bisnis pedagang di toko tradisional karena adanya pergeseran kebiasaan konsumen, jarak atau posisi yang berdekatan antara toko modern dan tradisional.
\end{abstract}

Kata kunci: implementasi, indomaret, peminggiran, pedagang kecil, toko modern

\section{WHO OWNS INDOMARET? \\ IMPLEMENTATION AND MARGINALIZATION OF POOR SELLERS IN THE PRACTICE OF GIVING PERMITS TO ESTABLISH A MODERN SHOP IN MEULABOH}

\begin{abstract}
Implementation of the Republic of Indonesia's Minister of Trade Regulation regarding the presence of modern shops such as Indomaret in Meulaboh City, West Aceh Regency, which has an impact on the large number of Indomarets and disrupts the existence of traditional shops owned by local communities. This study used a qualitative method through a case study
\end{abstract}


approach with key informants as Head of Trade at the Trade Office, Head of Services and Licensing Staff of the One-Stop Integrated Investment and Services Office (DPMPTSP), Secretary of the West Aceh Traders Association, Modern Shop Employees (Indomaret), Traditional Traders / Grocer and Community Traders. The results of this study indicate that the implementation of the Permendagri issuance, especially related to structuring guidelines and fostering of traditional markets, shopping centers and modern shops carried out by the Regional Government of West Aceh Regency has not been fully effective, it is due to the absence of derivative policies governing further related the establishment of modern markets such as Indomaret, and in the implementation there is also communication and non-coordination between the two parties implementing the policy. Aside from having positive impacts such as increasing local revenue tax, Indomaret's presence also has a negative impact because it increasingly marginalizes and even kills merchant businesses in traditional shops due to shifts in consumer habits, distance or adjacent positions between modern and traditional stores.

Keywords: implementation, Indomaret, marginalization, small traders, modern shops

PENDAHULUAN

Implementasi kebijakan

pemerintah melalui Peraturan Menteri

Perdagangan Republik Indonesia

khususnya Nomor 70/M-

DAG/PER/12/2013 berdampak pada

keberadaan indomaret terhadap

keberlangsungan eksistensi ritel

tradisional atau toko kelontong di Kota

Meulaboh. Salah satunya seperti yang

terlihat di Kota Meulaboh Kabupaten

Aceh Barat, Jaringan ritel waralaba

seperti indomaret sudah mulai menjamur dan berkembang di Kota Meulaboh.

Hingga saat ini jumlah dari pendirian indomaret di kawasan Kota Meulaboh sudah tersebar sebanyak 8 gerai. Yang tersebar di berbagai kawasan yang ada di daerah Kota Meulaboh Kabupaten Aceh Barat, diantaranya sebanyak 7 gerai indomaret tersebut berada di Kecamatan Johan Pahlawan, sedangkan sisanya lagi berada di Kecamatan Meureubo sebanyak 1 gerai. Dengan hadir dan berkembangnya supermarket dan minimarket seperti indomaret, dan usaha-usaha modern lainnya sebagai usaha modern berdampak terhadap pendapatan dan pertumbuhan ekonomi pedagang kecil seperti toko kelontong atau pedagang eceran lainnya.

Dengan semakin berkembang nya usaha toko modern seperti indomaret maka konsumen atau masyarakat lebih memilih berbelanja ke toko modern seperti indomaret yang menawarkan berbagai fasilitas, kemudahan, kebersihan dan kenyamanan yang dapat menarik minat konsumen atau masyarakat yang biasa berbelanja di toko kelontong atau pedagang eceran berpindah berbelanja ke minimarket seperti indomaret. Terlebih lagi minimarket atau indomaret juga sering mengadakan promosi atau penawaran bonus maupun keuntungan lainnya untuk menarik minat belanja konsumen untuk berbelanja ditempat mereka.

Kehadiran toko modern sudah pasti sangat mempengaruhi penjualan pedagang kecil atau toko kelontong, karena saingan pedagang kecil semakin bertambah dengan hadirnya usaha 
modern atau minimarket seperti indomaret yang memiliki keunggulan dari berbagai fasilitas, kenyaman dan kemudahan, kualitas produk maupun pelayanan dalam berbelanja yang lebih bagus dari pada dengan yang ditawarkan oleh pedagang kecil atau toko kelontong. Permasalahan juga muncul karena produk yang ditawarkan oleh toko modern pada umumnya identik dengan produk yang ditawarkan oleh pedagang kecil atau toko kelontong, karena hal tersebut konsumen atau masyarakat memiliki persepsi untuk lebih tertarik berbelanja di ritel modern seperti indomaret yang lebih banyak memiliki keunggulan dari pada harus berbelanja di pasar tradisional atau toko kelontong seperti yang ditawarkan oleh pedagang kecil. $\mathrm{Hal}$ ini akan mengurangi kemampuan ritel tradisonal seperti pedagang kecil dalam menjangkau para konsumen atau pelanggannya.

Ditambah lagi dengan kondisi yang lebih buruk pendirian indomaret juga dibangun sangat dekat atau rapat dengan toko kecil lainnya. Kondisi yang seperti inilah yang sangat dikhawatirkan akan berdampak pada semangat dari pedagang kecil akan menurun bahkan tidak menutup kemungkinan dapat mematikan usaha mereka. Pesatnya pertumbuhan dan perkembangan toko modern tentu saja harus diimbangi dengan kepastian hukum dan kebijakan terutama regulasi perdagangan agar tercipta iklim kepastian usaha dan tertib usaha.
Di dalam peraturan menteri perdagangan tentang syarat mendirikan pasar tradisional, pusat perbelanjaan dan toko modern maka wajib mematuhi ketentuan yang ditetapkan oleh Pemerintah Daerah terutama terkait penetapan jumlah serta jarak ideal keberadaan toko modern. Namun demkian, pemerintah juga memiliki pertimbangan penting yang tidak dapat dinegosiasikan seperti: mempertimbangkan tiingkat kepadatan dan pertumbuhan penduduk di lokasi yang akan didirikan toko modern; (2), memperhatikan dan mempertimbangkan potensi ekonomi yang dimiliki masyarakat setempat; (3) arus lalu lintas (aksessibilitas wilayah); (4) kepastian keamanan dan dukungan infratruktur yang memadai; (5) hadirnya pemukiman baru; (6) gaya hidup dan pola konsumsi masyarakat; dan (7) Sistem kerja dan jam buka toko modern tidak mematikan toko lainnya.

Sebuah toko baik yang tradisional maupun modern yang ingin membuka usahanya, sesuai peraturan menteri perdagangan, harus mengurus dan memiliki izin mendirikan toko modern sebagai legalitas hukum. Izin usaha tersebut berupa: a) IUPP bagi Mall, Plasa, Pertokoan, dan Pusat Perdagangan; b) IUPPT untuk Pasar Tradisional; dan c) IUTM untuk perkulakan, Department Store, Hypermarket, Minimarket, dan Supermarket. Namun khusus bagi toko modern, setiap pengusaha harus melengkapi persyaratan seperti fotokopi surat izin prinsip dari gubernur, 
fotokopi surat izin lokasi dari dinas perdagangan, fotokopi surat Izin Undang-Undang Gangguan (HO), fotokopi Surat Izin Mendirikan Bangunan (IMB), fotokopi akte pendirian dan/atau perubahan perusahaan dan pengesahannya bagi perusahaan yang berbadan hukum Perseroan Terbatas atau Koperasi, dokumen hasil analisa kondisi sosial ekonomi masyarakat dan rekomendasi dari dinas perdagangan, dan terakhir rencana kemitraan dengan Usaha Mikro dan Usaha Kecil. Tujuannya adalah diharapkan peraturan menteri ini dapat menjadi perlindungan hukum khususnya bagi ritel tradisional.

Ada banyak penelitian terdahulu terkait dan toko tradisional dan toko modern yang diposisikan saling berhadapan. Selain itu, terdapat dua paradigma ketika berbicara mengenai toko modern, yaitu kelompok pro dan kelompok kontra terhadap keberadaan toko modern seperti indomaret. Kelompok pro mengatakan bahwa sebab kelesuan toko tradisional bukan akibat hadirnya toko modern melainkan problematika internal seperti buruknya manajeman dan fasilitas yang disediakan toko serta akibat masih sedikitnya bantuan modal dan insentif yang diberikan pemerintah kepada pedagang traditional (kecil). Bahkan, hadirnnya toko modern juga dianggap oleh kelompok pro sebagai upaya untuk meningkatkan pertumbuhan ekonomi dan membentuk iklim persaingan yang sehat (Suryadarma \& Rosfadhila, 2007).
Sedangkan untuk pendapat yang kontra terdapat beberapa penelitian dari para peneliti lainnya mengatakan bahwa perubahan preferensi atau minat belanja di dalam masyarakat misalnya dengan mengalihkan tempat belanja dari toko tradisional ke toko modern merupakan pilihan rasional konsumen karena penilaian kualitas barang yang baik dan harga yang relatif lebih murah yang akhirnya berdampak pada regulasi yang lebih berpihak pada toko modern dan semakin menggeser eksistensi toko tradisional dan di tahap terjauh akan mempercepat hilangnya toko tradisional di Indonesia (Hidayat, 2008). Data Asosiasi Pedagang Pasar Seluruh Indonesia (APPSI) menyebutkan bahwa hypermart adalah salah satu sebab gulung tikarnya toko dan kios pedagang kecil-menengah, bahkan di Jakarta terdapat delapan pasar tradisional dan 400 kios yang tutup setiap tahun karena kalah bersaing dengan hypermart dan pedagang yang bertahan di Bandung mengalami penurunan omzet hingga $40 \%$ (Nielsen, 2005).

Kemudian pendapat lain menyimpulkan bahwa beberadaan alfamart dan indomaret yang posisinya selalu berdekatan dan mendominasi usaha-usaha kecil warga sekitar tentunya akan memberikan pengaruh terhadap perekonomian usaha kecil. Pengaruhnya antara lain kehilangan pelanggan tetap yang nantinya berdampak pada mengurangi keuntungan, omzet dan penjualan fisik. Selain itu adanya pengurangan tenaga kerja yang dilakukan oleh pemilik toko terhadap karyawannya dan memberlakukan jam buka toko yang lebih panjang dari sebelumnya pun 
dilakukan dengan tujuan guna mengantisipasi kerugian yang lebih besar dikarenakan turunnya penjualan (Shinta Wahyu Hati \& Chandra, 2018). Kondisi ini menunjukkan bahwa memang benar adanya keberadaan retail modern seperti minimarket mengakibatkan waktu operasional warung-warung tradisional menjadi lebih lama dari sebelumnya dan menurunnya omzet pendapatan warung-warung tradisional dalam presentase sebesar 25\% (Listihana , W.D, Aquino, A, 2014).

Implementasi kebijakan adalah keseluruhan proses dalam kegiatan administratif bernegara dan baru dinyatakan dimulai ketika sasaran, tujuan, dan program dan dana telah tersusun dan disalurkan (Grindle, 1980). Implementasi kebijakan juga dapat berarti tindakan yang dilakukan pemerintah yang dimaksudkan untuk mencapai tujuan (Parsons, 1995). Setidaknya terdapat empat sebab berhasil atau tidaknya implementasi kebijakan yaitu komunikasi, sumber daya, sikap birokrasi atau pelaksana dan struktur organisasi, termasuk tata aliran kerja birokrasi (Edward III, 1984).

\section{METODE}

Metode kualitatif dengan pendekatan case-study dilakukan karena pertimbangan bahwa Implementasi Peraturan Menteri Perdagangan Republik Indonesia berdampak terhadap keberadaan indomaret di Kota Meulaboh Kabupaten Aceh Barat, dan hanya dapat di pahami dengan melihat secara lebih insight-deep bersumber dari berbagai informasi yang ada. Dalam upaya untuk mendapatkan data penelitian maka mewawancarai bersama narasumber dilakukan dengan mengajukan pertanyaan-pertanyaan. Informasi yang disampaikan oleh narasumber yang dikumpulkan dalam berupa teks tulisan untuk selanjutnya dianalisis secara mendalam agar memudahkan peneliti menggambarkan, menginterpretasi, dan memaknai sebuah peristiwa. Sesudahnya peneliti membuat permenungan pribadi (self-reflection) dan menjabarkannya hasil penelitian lainnya (Creswell, 2015).

Penelitian ini dilakukan di Aceh Barat khususnya di Dinas Perdagangan, Dinas Penanaman Modal dan Pelayanan Terpadu Satu Pintu (DPMPTSP), Lembaga Ikatan Pedagang Kabupaten Aceh Barat, beberapa toko modern dan toko tradisional seperti toko kelontong atau kios-kios kecil yang yang berdiri dekat atau bersebelahan dengan supermarket maupun minimarket seperti indomaret yang berada di daerah Kota Meulaboh Kabupaten Aceh Barat dan sekitarnya. Alasan peneliti memilih lokasi ini karena lebih dekat dengan tempat tinggal, mudah dijangkau dan ekonomis.

Narasumber penelitian ini dipilih dengan pertimbangan dan kriteria yang sesuai dengan tujuan penelitian yang akan dilakukan dengan teknik purposive atau ditentukan terlebih dahulu berdasarkan pengetahuan dan keahlian yang dimiliki, jumlah narasumber dalam penelitian ini adalah 16 orang sebagaimana berikut pada tabel 1 
Tabel 1. Penentuan Narasumber

\begin{tabular}{cll}
\hline NO & \multicolumn{1}{c}{ Narasumber } & Jumlah \\
\hline 1. & $\begin{array}{l}\text { Kepala Bidang Perdagangan Dinas } \\
\text { Kabupaten Aceh Barat }\end{array}$ & Perdagangan \\
\hline 2. & $\begin{array}{l}\text { Kasi Pelayanan \& Staff Perizinan Dinas Penanaman Modal } \\
\text { Dan Pelayanan Terpadu Satu Pintu (DPMPTSP) Kabupaten } \\
\end{array}$ & 2 Orang \\
\hline Aceh Barat & Sekretaris Ikatan Pedagang Kabupaten Aceh Barat & 1 Orang \\
\hline 3. & Karyawan Toko Modern (Indomaret) & 3 Orang \\
\hline 5. & Pedagang Tradisional / Pedagang Kelontong & 3 Orang \\
\hline 6. & Pelanggan Indomaret / Masyarakat & 6 Orang \\
\hline Jumlah Keseluruhan & 16 Orang
\end{tabular}

Sumber: Diolah peneliti dari data lapangan, 2019

Analisis data yang digunakan adalah teknik analisa deskriptif dengan pendekatan kualitatif yaitu menjabarkan hasil penelitian sebagaimana adanya artinya data yang diperoleh di lapangan selanjutnya dikumpulkan, diklasifikasi, dan dianalisis untuk ditemukan kesimpulan penelitian.

\section{HASIL DAN PEMBAHASAN}

\section{Gambaran Umum Objek dan Lokasi Penelitian}

Data Dinas Kependudukan dan Pencatatan Sipil Aceh Barat menunjukkan pada tahun 2016 jumlah penduduk di Kabupaten Aceh Barat sebanyak 187.700 jiwa. Penduduk terbanyak berada di Kecamatan Johan Pahlawan, yaitu 50.078 jiwa. Diikuti oleh Kecamatan Meurebo sebanyak 29.004 dan Kawai 20.267 jiwa. Dua kecamatan ini memang berdekatan dengan Kota Meulaboh sebagai pusat kota di Aceh Barat. Penduduk terkecil berada di Kecamatan Sungai Mas dan Woyla Timur masing-masing sebanyak 4.025 dan 5.262 jiwa. Kedua Kecamatan ini berada paling jauh dengan Kota Meulaboh.

Dalam menjalankan tugasnya, Dinas Penanaman Modal dan Pelayanan Terpadu Satu Pintu (DPMPTSP) Kabupaten Aceh Barat memiliki visi yang sejalan dengan visi Bupati terpilih tahun 2017-2022, Adapun visi DPMPTSP Kabupaten Aceh Barat adalah "Terwujudnya Pelayanan Investasi dan Perizinan Yang Mudah, Transparan, Akuntabel dan Kredibel". Dan visi tersebut diaktualisasi dengan misi, yaitu: (1) menciptakan iklim investasi penanaman modal yang nyaman dan kondusif dan (2) meningkatnya Pelayanan PTSP yang berkualitas.

Berbicara mengenai perizinan maka tidak lepas dari perizinan atas pendirian toko modern seperti indomaret di Aceh Barat, bagaimana tidak, untuk sebuah kota kecil seperti Meulaboh, telah berdiri 8 toko indomaret dengan rincian tujuh gerai indomaret di Kecamatan Johan 
Pahlawan, sedangkan sisanya yaitu satu Berikut rinciannya disajikan pada tabel 2 gerai berada di Kecamatan Meureubo.

Tabel 2 Lokasi pendirian indomaret di Kota Meulaboh

\begin{tabular}{cll}
\hline No. & \multicolumn{1}{c}{ Lokasi Pendirian Indomaret } & \multicolumn{1}{c}{ Kecamatan } \\
\hline 1. & Jalan Sisingamangaraja, Dusun III, Gampong Gampa. & Johan Pahlawan \\
\hline 2. & Jalan Teuku Umar No.5-6, Gampong Ujong Kalak. & Johan Pahlawan \\
\hline 3. & $\begin{array}{l}\text { Jalan Manek Roo No.3-4, Dusun Mangga, Gampong } \\
\text { Ujong Baroh. }\end{array}$ & Johan Pahlawan \\
\hline 4. & Jalan Imam Bonjol Komplek SPBU, Dusun Teuku & Johan Pahlawan \\
& Umar, Gampong Suak Raya. & \\
\hline 5. Jalan Nasional No.107, Gampong Ujong Baroh. & Johan Pahlawan \\
\hline 6. Jalan Gadjah Mada (Depan RSU Tjut Nyak Dhien). & Johan Pahlawan \\
\hline 7. Jalan Imam Bonjol, Gampong Seunebok (Depan & Meurebo \\
\hline & Mesjid Agung Baitul Makmur). & \\
\hline 8. Jalan Nasional Meulaboh-Tapaktuan Km.3,5 &
\end{tabular}

Sumber: Diolah dari hasil penelitian, 2019

Pedoman penataan dan pembinaan pasar tradisional, pusat perbelanjaan dan toko modern telah diatur oleh Peraturan Menteri Perdagangan Republik yaitu berpedoman pada zonasi dan patuh pada rencana tata ruang wilayah. Adapun alur perizinan pendirian toko modern seperti indomaret adalah wajib memiliki izin sebagai legalitas usaha bagi pelaku usaha yang melakukan kegiatan usaha di bidang Pasar Tradisional, Pusat Perbelanjaan dan Toko Modern. Namun pada tahun 2015, toko modern seperti indomaret sudah resmi dibuka dan dikeluarkan izin legalitasnya dan di beberapa kejadian dianggap oleh pedagang kecil melanggar system zonasi. Hal inilah yang menjadi problematika di dalam dunia kebijakan Pemerintah Daerah Aceh Barat karena tidak ada pembatasan pendirian dan perkembangan toko modern yang akhirnya berdampak negatif terhadap keberlangsungan eksistensi toko tradisional. Berikut disajikan pada gambar 1 Toko Indomaret yang ada di meulbaoh

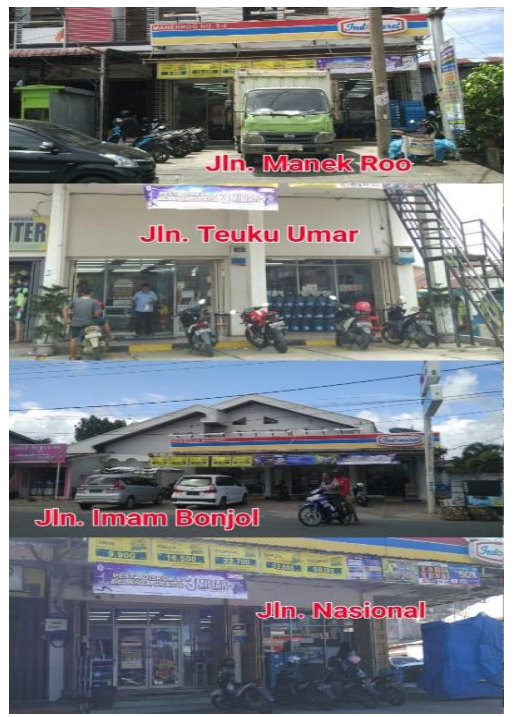

Gambar 1. Pendirian gerai indomaret di berbagai sudut Kota Meulaboh

Sumber: Dokumentasi Peneliti, 2019 
2. Peraturan Menteri Perdagangan versus Implementasi di Lapangan

Dalam proses implementasi peraturan menteri perdagangan tersebut belum sepenuhnya berjalan dengan efektif, hal tersebut sangat jelas terlihat pada sistem komunikasinya, selama ini komunikasi yang dibangun antar lembaga terkait masih belum efektif dikarenakan terjadi misskomunikasi di antara pelaksana kebijakan seperti yang terjadi antara Dinas Penanaman Modal dan Pelayanan Terpadu Satu Pintu (DPMPTSP) beserta Dinas Perdagangan Kota. Misalnya, DPMPTSP mengatakan izin yang mereka keluarkan sudah sesuai dengan SOP (Standart Operation Procedur) yang berlakuizin keluar sesuai rekomendasi dari petugas lapangan dari Dinas Perdagangan Kabupaten Aceh Barat yang meninjau lokasi terkait layak atau tidaknya pendirian indomaret.

Namun hal tersebut tidak dibenarkan oleh pihak dari Dinas Perdagangan Kabupaten Aceh Barat, pihak Dinas Perdagangan menganggap bahwa pihak dari DPMPTSP dalam mengeluarkan izin pendirian indomaret di Kota Meulaboh tidak pernah berkoordinasi dengan pihak mereka, Dinas Perdagangan juga menganggap bahwa pihak DPMPTSP dalam mengeluarkan izin terkait pendirian indomaret di Kota Meulaboh hanya memutuskan secara sepihak saja tanpa melibatkan pihak dari Dinas Perdagangan untuk mengeluarkan izin pendirian indomaret. Karena dalam hal ini pihak dari Dinas Perdagangan Kota
Meulaboh menganggap bahwa merekalah yang lebih berhak untuk mengatur terkait pendirian indomaret di Kota Meulaboh. Maka dalam hal ini sangat jelas terlihat bahwa diantara pihak pelaksana kebijakan terjadi misskomunikasi dan adanya ego sektoral dalam menjalankan aturan yang akan dilaksanakan.

Selain itu juga terdapat kendala dari aspek koordinasi, sosialisasi, sumber daya manusia dan sumber daya non manusia seperti keterbatasan jumlah personel dan kemampuan dari petugas dil lapangan dan juga ketersediaan fasilitas yang dibutuhkan oleh para pelaksana dalam implementasi kebijakan. Selain itu juga terdapat kendala komunikasi dan disposisi/sikap pelaksana kebijakan di Kabupaten Aceh Barat dapat diketahui bahwa selama ini sikap dari para pelaksana kebijakan masih acuh tak acuh dalam proses pelaksanaan implementasi.

Hal ini dapat terlihat pada masalah yang terdapat pada pendirian izin indomaret di Kota Meulaboh Kabupaten Aceh Barat, komitmen dan kemauan dari para pelaksana kebijakan untuk membuat dan menetapkan kebijakan seperti Perbup atau Qanun yang mengatur lebih lanjut tentang izin, jumlah, jarak dan hal lainnya yang menyangkut dari pendirian indomaret masih acuh tak acuh. Para pelaksana kebijakan selama ini hanya berencana tentang pembuatan peraturan kebijakan tersebut, namun hal itu tidak kunjung direalisasikan. Apabila wacana 
dari para pelaksana kebijakan tersebut tidak kunjung direalisasikan maka akan berdampak buruk terhadap keberlangsungan eksistensi pasar tradisional dan akan sangat berpengaruh terhadap semangat dan menurunnya pendapatan dari para pedagang tradisional di Kota Meulaboh Kabupaten Aceh Barat karena indomaret terus berkembang setiap tahunnya dan mulai menjamur di berbagai sudut Kota Meulaboh Kabupaten Aceh Barat.

Hal tersebut terlihat dalam proses pendirian izin indomaret di Kota Meulaboh Kabupaten Aceh Barat, komitmen dan kemauan dari para pelaksana kebijakan untuk membuat dan menetapkan kebijakan seperti Perbup atau Qanun yang mengatur lebih lanjut tentang izin, jumlah, jarak dan hal lainnya yang menyangkut dari pendirian indomaret masih acuh tak acuh. Para pelaksana kebijakan selama ini hanya berencana tentang pembuatan peraturan kebijakan tersebut, namun hal itu tidak kunjung direalisasikan. Apabila wacana dari para pelaksana kebijakan tersebut tidak kunjung direalisasikan maka akan berdampak buruk terhadap keberlangsungan eksistensi pasar tradisional dan akan sangat berpengaruh terhadap semangat dan menurunnya pendapatan dari para pedagang tradisional di Kota Meulaboh Kabupaten Aceh Barat karena indomaret terus berkembang setiap tahunnya dan mulai menjamur di berbagai sudut Kota Meulaboh Kabupaten Aceh Barat.

\section{Dampak Pendirian Indomaret bagi Pedagang Kecil dan Masyarakat}

Berbagai kalangan menganggap bahwa kehadiran toko modern seperti indomaret memang memberikan dampak positif dan dampak negatif tersendiri, hadir dan berkembangnya toko modern di Kabupaten Aceh Barat memiliki dampak positif antara lain : (1) Memberikan perkembangan suatu daerah khususnya di Ibu Kota Meulaboh Kabupaten Aceh Barat menjadi lebih maju; (2) Meningkatkkan pajak pendapatan asli daerah melalui pembayaran pajak dari pendirian usaha seperti indomaret di Kota Meulaboh Kabupaten Aceh Barat. Namun disisi lain hal tersebut juga memberikan dampak negatif yaitu : (1) Dapat mematikan usaha pedagang di pasar tradisional karena adanya pergeseran kebiasaan konsumen dan hal ini juga menyebabkan semangat dari para pedagang kecil menurun; (2) jarak yang terlampau dekat antara indomaret dan took kelontong kecil menjadi sebab pindahnya pembeli di toko tradisional ke toko modern; (3) Terjadi penurunan pendapatan para pedagang kecil. Dibawah ini ditampilkan pada gambar 2 tentang salah satu lokasi pendirian gerai indomaret yang dibangun sangat berdekatan dengan toko kelontong yang berada disebelahnya. 


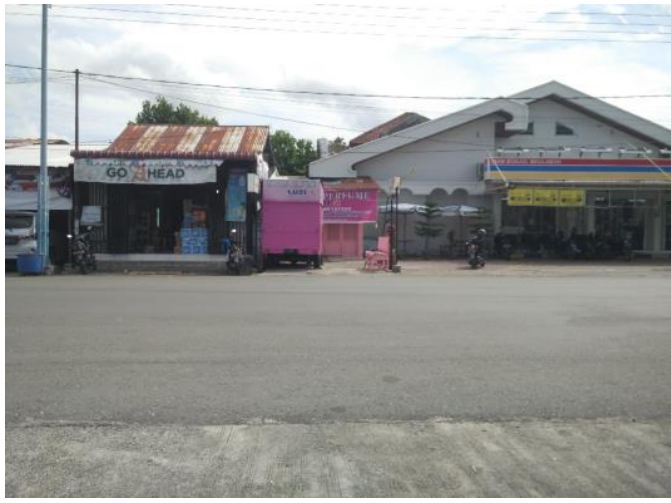

Gambar 2 Lokasi pendirian gerai indomaret yang berdekatan dengan toko kelontong kecil

Sumber: Dokumentasi Peneliti, 2019

Adapun terkait izin dan lokasi dari pendirian indomaret di Kota Meulaboh ini diperlukan komitmen, sikap, dan tindakan tegas pemerintah sebagai pelaksana kebijakan untuk segera merealisasikan janjinya dalam hal men-stop permohonan izin baru karena saat ini indomaret banyak di bangun di lokasi dan jarak yang sangat berdekatan dan mendapat penolakan ari para pedagang tradisional karena mengancam keberlangsungan eksistensi pasar tradisional.

\section{SIMPULAN}

Implementasi Peraturan Menteri Perdagangan Republik Indonesia terkait penataan toko modern di Aceh Barat belum sepenuhnya berjalan dengan efektif dan mengalami beberapa hambatan. Faktor penghambat tersebut seperti masih kurangnya sumber daya manusia, misskomunikasi, hingga lemahnya disposisi dan sikap pelaksana kebijakan. Namun demikian, juga terdapat faktor yang mendukung proses keberhasilan implementasi telah ada mekanisme struktur birokrasi dan dan
SOP (Standart Operation Procedur) sebagai pedoman bagi setiap pelaksana kebijakan agar tidak melenceng dari tujuan dan sasaran kebijakan.

Kehadiran toko modern seperti indomaret di Kota Meulaboh bedampak positif dan negative bagi perkembangan daerah. Dampak positifnya adalah mampu meningkatkkan pajak pendapatan asli daerah (PAD), sedangkan dampak negatifnya adalah mematikan usaha pedagang tradisional akibat pergeseran kebiasaan konsumen dan hal ini juga menyebabkan semangat dari para pedagang kecil menurun, kemudian jarak atau posisi yang berdekatan antara toko modern dan toko tradisional berimbas pada perpindahan minat beli dari toko tradisional ke toko modern. Kemudian dampak negatif lainnnya ialah para pedagang di pasar tradisional Kota Meulaboh Kabupaten Aceh Barat juga mengalami penurunan dari segi pendapatan yang mereka dapatkan.

\section{DAFTAR PUSTAKA}

Creswell, J. W. (2015). Penelitian Kualitatif \& Desain Riset. Yogyakarta: Pustaka Pelajar.

Edward III, G. C. (1984). Public Policy Implementing. London-England: Jai Press Inc.

Grindle, M. S. (1980). Politic and Policy Implementation in The Third World. New Jersey: Princinton University Press.

Hasan, I. (2002). Metode Penelitian dan Aplikasinya. Jakarta: Ghalia Indonesia.

Herdiansyah, H. (2010). Metodologi 
Penelitian Kualitatif. Salemba Humanika.

Hidayat, U. (2008). Preferensi Konsumen : Strategi Pengembangan Pasar Tradisional. 9(2).

Listihana, W.D, Aquino, A, A. (2014). Dampak Keberadaan Minimarket Terhadap Modal Kerja dan Pendapatan Warung Tradisional di Kecamatan Rumbai dan Rumbai Pesisir Kota Pekanbaru. IImiah Ekonomi dan Bisnis, 11(1), 533562.

Moleong, J. L. (2010). Metodologi Penelitian Kualitatif. Bandung: Remaja Rosydakarya.

Nielsen, A. . (2005). Asia Pasific Retail and Shopper Trends. Diambil dari http://www.acnielsen.de/pubs/doc uments/RetailandShopperTrendsA sia2005.pdf.

Nofrizal. (2018). Implementasi Peraturan Bupati Nomor 5 Tahun 2010 Tentang Pemakaian Busana Muslim di Kabupaten Aceh Barat 2016-2017. Universitas Teuku Umar.

Palnitkar. (2015). The International Journal of Business \& Management. 3(11), 63-70.

Parsons, T. (1995). Sistem Sosial: Kerangka Konseptual untuk Menganalisis Struktur Masyarakat (A. Sudardja, Ed.). Jawa Barat: Ikatan Sosiologi Indonesia.

Sadilah, E. (2011). Eksistensi Pasar Tradisional. Yogyakarta: Balai Pelestarian Sejarah dan Nilai Tradisional.

Setyorini, T. (2013). Kebijakan Pemkab Bantul dalam Menangani Menjamurnya Toko Modern. PMI, $X(2)$.

Shinta Wahyu Hati \& Chandra, N.
(2018). Jurnal Pemikiran dan Penelitian Administrasi Bisnis dan Kewirausahaan. 3(1).

Soehartono, I. (2008). Metode Penelitian Sosial. Bandung: PT Remaja Rosdakarya.

Subandi. (2005, Desember). Harian Suara Merdeka.

Sugiyono. (2008). Metode Penelitian Bisnis (Pendekatan Kuantitatif, Kualitatif dan R\&D). Bandung: Alfabeta.

Suryadarma \& Rosfadhila. (2007). Impact of Supermarkets on Traditional Markets and Retailes in Indonesia's Urban Centers.

Josep, T. (2017). Pengaruh Potongan Harga Terhadap Keputusan Pembelian di Indomaret Lampung Utara Kecamatan Kotabumi Utara. Universitas Lampung.

Widodo, Joko. (2010). Analisis Proses Kebijakan Publik. Malang: Bayu Media.

Wiratno, Wijayanti, P. (2011). Analisis Pengaruh Keberadaan Keuntungan Usaha Warung Tradisional dengan Munculnya Minimarket. Universitas Diponegoro, Diponegoro. 